\title{
LEAF-LITTER SPIDER DIVERSITY IN THE TROPICAL FOREST OF NORTHERN VIETNAM IN RELATION TO REGIONAL CONDITION AND HABITAT STRUCTURE
}

\author{
Pham Dinh Sac ${ }^{1 *}$, Tran Thi Anh Thu ${ }^{2}$, Li Shuqiang ${ }^{3}$ \\ ${ }^{(1 *)}$ Institute of Ecology and Biological Resources, VAST, phamdinhsac@ gmail.com \\ ${ }^{(2)}$ Can Tho University, Vietnam \\ ${ }^{(3)}$ Institute of Zoology, Chinese Academy of Sciences, Beijing, China
}

\begin{abstract}
A survey of leaf-litter spiders was carried out in April 2008 and March 2009 at three National Parks in Northern Vietnam, such as, Cuc Phuong National Park (CPNP, red river delta tropical monsoon climate), Tam Dao National Park (TDNP, high mountain tropical monsoon climate) and Cat Ba National Park (CBNP, maritime climate). Four types of habitat chosen at each region are natural forest and disturbed forest (have multi-layer vegetation structure), shrub-land and acacia plantation (have simple-layer vegetation structure). The spiders were sampled by leaf-litter sieving. A total of 8787 adults (251 species, 33 families) from three regions were found, including 2846 adults (142 species) in CPNP, 3184 (137) in TDNP and 2757 (124) in CBNP. Sheet-line weavers and cursorial hunters were the dominant guilds at study area. The MDS plots and ANOSIM analyses used to compare the diversity of leaf-litter spiders between regions and between habitats. The species composition of three regions was significantly different between region with maritime climate conditon (CBNP) and the rest regions. The abundance, species richness and diversity index were higher in habitats that multi-layer vegetation structure. The species and guild composition were considerably different between two types of habitat. The relationships between diversity of leaf-litter spiders and habitat structure as well as the different in species composition between regions have been discussed in the paper.
\end{abstract}

Key words: diversity, leaf-litter spider, regional condition, tropical forest, vegetation structure, Northern Vietnam.

\section{INTRODUCTION}

Leaf-litter spiders are those inhabiting the forest-floor litter layer. Communities of leaflitter spiders frequently exhibit both high family diversity and numerical abundance [43]. The studies of Wise (1993), Wagner and Wise $(1996$, 1997) [43, 39] suggested that the structural complexity of the leaf litter itself may facilitate the persistence of this high diversity of predators. Because litter spiders are linked to and reflect habitat structure and prey abundance, they also can act as indicators [20]. Leaf-litter spiders had been used as indicators to monitor redwood forest restoration [42] and evaluate the effects of wildfire [21].

While prey abundance accounted for a statistically significant amount of variation in leaf-litter spider diversity during the early summer months, litter depth, complexity and temperature were more important during middle and late season [31-33]. One possible explanation may be that as the structural complexity of the litter increased, the surface area and diversity of potential foraging spaces within the leaves also increased. In particular, the spaces within curled leaves, the underside of twisted leaves or the gaps between leaves create unique foraging sites for a diversity of spiders $[29,34]$. Like other litter arthropod communities, litter spider community can vary along elevation gradient $[22,36]$, habitat complexity $[8,41,36,1]$. Their abundance can relative to availability of nutrients [33,23], litter depth and complexity $[33,5,6,38,40]$ and fluctuation in environment conditions [12].

Herein we present an assessment of diversity patterns for a leaf-litter spider community in the tropical forests in Northern Vietnam. Our first goal was to compare the community structure and species composition of spiders between three regions are different in climate condition. Our second goal was to relate vegetation structural variables of each type of habitat with that of spider fauna and quantify 
the faunal similarity among different habitat types.

\section{MATERIALS AND METHODS}

\section{Study area}

The study was carried out at three regions (CPNP, TDNP and CBNP) in Northern Vietnam, separated by $140-160 \mathrm{~km}$ (fig. 1).

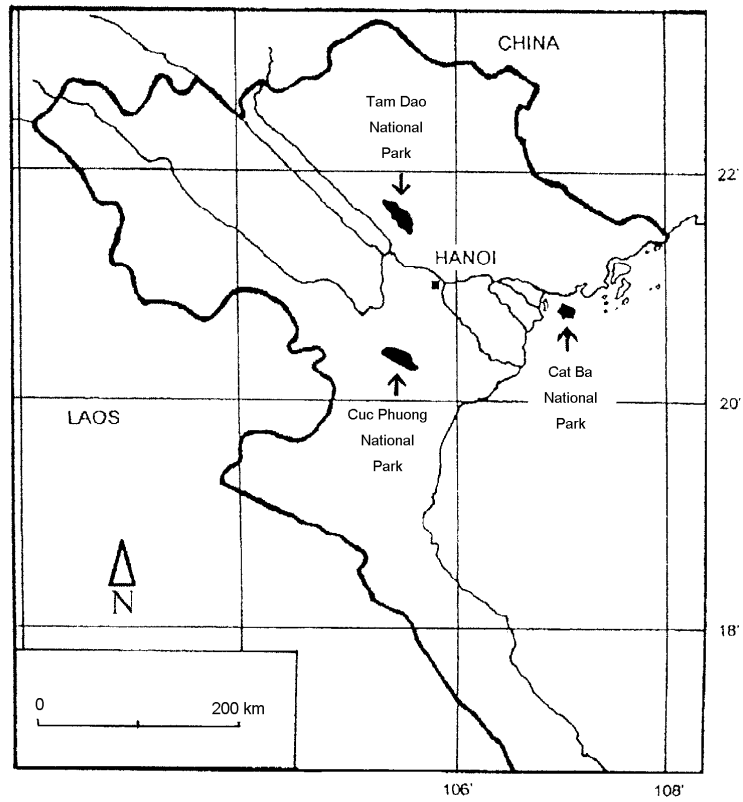

Figure 1. Map of Northern Vietnam and the location study regions

Cuc Phuong National Park (CPNP) is situated from $20^{\circ} 14^{\prime}-20^{\circ} 24^{\prime} \mathrm{N}$ and $105^{\circ} 29^{\prime}$ $105^{\circ} 44^{\prime} \mathrm{E}$ and occupied about 22,200 ha. The park belongs to Ninh Binh province, at elevation 154-636 $\mathrm{m}$ above sea level. It is located in the red river delta tropical monsoon climate area with stability in factors of weather, such as, temperatures, humidity gradient.

Tam Dao National Park (TDNP) (21 $21^{\circ}$ $\left.21^{\circ} 42^{\prime} \mathrm{N}, 105^{\circ} 23^{\prime}-105^{\circ} 44^{\prime} \mathrm{E}\right)$ belongs to Vinh Phuc province, total area of the park is 36,833 ha and varies in elevation from $900-1388 \mathrm{~m}$. Locating in the area with typical characters of high mountain tropical monsoon climate, TDNP has high humidity, while temperature is very low. It is misting and rain together strong win are regular occurrence in this region [10].

Cat Ba National Park (CBNP) differs from other national parks in Vietnam by locating in island areas that lies $20 \mathrm{~km}$ due east of Hai
Phong province. Due to the isolated nature of the island, the diversity and abundance of mammals at CBNP are low compared to other national parks in Vietnam. The park is located between $20^{\circ} 44^{\prime}-20^{\circ} 51^{\prime} \mathrm{N}$ and $106^{\circ} 58^{\prime}-107^{\circ} 10^{\prime} \mathrm{E}$ and it covers an area of 15,200 ha, at elevation from 25-331 $\mathrm{m}$. The CBNP affected by maritime climate with weather fluctuation. In addition, typhoons and tropical storms are frequent in the rainy season.

\section{Sampling sites}

Spiders were sampled at four types of habitats in each region. Natural forests and disturbed forests belong to types of multi-LVS (four or five vegetation layers). Shrub-land and acacia plantation belong to types of simple-LVS (one vegetation layer).

\section{Natural forests (NATF)}

A five layers structures (A1-A5) follow Thai Van Trung (2000) [30].

The highest layer (A1) or emergent canopy consists of woody trees with height of over 30 $\mathrm{m}$ with scattered distribution.

The layer A2 is composed of woody trees of 20-30m high and makes out a big ecological dominant canopy.

Layer A3 is a canopy with plants of 8-20 m high and discontinuously distributed with some frequently-observed species.

Layer A4 consists of plants below $8 \mathrm{~m}$ high.

Layer A5 (forest floor) consists of weedy and shrubby plants.

\section{Disturbed forests (DISF)}

In the disturbed forest adjacent to the natural forest, the vegetation has four indistinct tree layers A2, A3, A4 and A5. The highest layer (Al) was absent in disturbed forest because of the logging caused by local people in the past.

\section{Shrub-lands (SHRL)}

The shrub-land are not natural but are derived from forest loss. The vegetation comprise only shrubs layer with 2-8 m high.

\section{Acacia plantation (ACAP)}

Two species of acacia planted commonly 
are Acacia auriculiformis and Acacia mangium. These species have been planted in Vietnam for many years. It covers an area of 926 ha in CPNP, 1530 ha in TDNP and 784 ha in CBNP [10, 37]. Acacia plantation has one tree layer of Acacia, with an average canopy height of $15-25 \mathrm{~m}$.

\section{Sampling methods}

Some methods used in sampling litter spiders are sieving, pitfall trap and Berlese funnel. However, litter sieving mainly sample more genera, species and individuals than other methods and contained a greater proportion of small species and specieal species [27].

This sifter consists of a heavy cloth cone about $80 \mathrm{~cm}$ in length, $30 \mathrm{~cm}$ in diameter at one end and $10 \mathrm{~cm}$ at the other. An open metal frame with a handle attached is sewn into the large end and another similar frame, to which a metal $13 \mathrm{~mm}$ mesh size grid is soldered, attached about $25 \mathrm{~cm}$ below the first one. The narrow end of the cone is tied shut with a rope, so that a bag is formed. Leaf-litter placed in the top of the bag rest on the grid, and we shake the sifter, fine debris, including spider falls through the grid and accumulate at the bottom. Then, using a peace of plastic for spread out the debris and collecting spiders.

At each region, four habitats were chose, each habitat consisting of five replications. The replications were established at least $50 \mathrm{~m}$ from the edge of the forest edge to reduce the edge effect and with a distance about $1.0 \mathrm{~km}$ from each of the five replications. Spiders sampled in four $0.25-\mathrm{m}^{2}$ litter samples per replication $\left(1-\mathrm{m}^{2}\right.$ litter samples in total per replication). Samplings were conducted every month between April 2008 and March 2009.

All adult spiders were identified to family and morpho-species. Juveniles were excluded from this study due to the extreme difficulties of identification to species level, however, a quantitative assessment of their identities at the family level suggested a similar frequency distribution as with adults [28].

\section{Statistical analyses}

Indices of the Margalef species richness $(d)$,
Pielou evenness $\left(J^{\prime}\right)$, Shannon - Weaver function $\left(H^{\prime}\right)$ and Simpson index $(D)$ of spider communities were assessed for each habitat type, and were calculated using Primer v5 software [24].

The Shannon-Weaver function and Simpson index used to compare the community structures of spiders among different regions and habitats. Samples having high species richness and equal abundance between species will generate higher $H$ values. Samples represented by few dominant species and many rare species will generate large $D$ values, therefore, the Simpson index can be used to assess the degree of dominance of the sample.

The Shannon - Weaver function $\left(H^{\prime}\right)$ and Simpson index $(D)$ are calculated by the following formulas: $H^{\prime}=-\sum P i \log P i ; D=1-\sum$ $(P i)^{2}$. Where $P i$ is the percentage of species $i$ in the total community.

The value of evenness ranges from 0 to 1 , which measures the degree of homogeneity in abundance between species. The species richness $(d)$ and evenness $\left(J^{\prime}\right)$ are calculated by the following formulas: $d=(S-1) \log (N) ; J^{\prime}=$ $H^{\prime} \log (S)$. Where $S$ is total species, $N$ is total individual.

The t-test of paired two samples for means was used to test the difference of diversity index (Shannon - Weaver function $H^{\prime}$ ) between habitat types by the following formula [28]:

$$
\mathrm{t}=\frac{H^{\prime}{ }_{1}-H_{2}^{\prime}}{\left[\operatorname{var}\left(H_{1}{ }^{\prime}\right)+\operatorname{var}\left(H_{2}{ }^{\prime}\right)\right]^{1 / 2}}
$$

The similarity among sampling sites was depicted as Bray - Curtis similarities, using both species and guild compositions. Multidimensional scaling plots (MDS) were constructed based upon similarity values. Analysis of similarities (ANOSIM) was performed between each pair of habitats and between regions to determine the signification level. The ANOSIM procedure of PRIMER is a nonparametric permutation procedure applied to rank similarity matrices underlying sample ordinations [9]. This method generates a global $\mathrm{R}$-statistic, which is a measure of the distance between groups. An R-value that approaches one indicates strongly distinct assemblages, 
whereas an R-value close to zero indicates that the assemblages are barely separable [9]. These $\mathrm{R}$-values were used to compare spider assemblages between regions and between habitats.

Where ANOSIM revealed significant differences between guilds, SIMPER analyses (PRIMER) were used to identify those guilds that contributed most to the observed assemblage differences [10]. Similarity percentages (SIMPER) allowed identification of species and guilds important in discriminating between groups that differed significantly from each other.

Species accumulation curves were employed to compare the completeness of our sampling for each region. It was compared theoretical or expected species accumulation curve, which describes the when data are randomly distributed among the samples. SPSS 15.0 computer program (SPSS Inc. USA) was used to perform this test.

\section{Guild composition}

Based on hunting methods and web building types from the literatures of Uetz (1999) [35], Hofer and Brescovits (2001) [14] we grouped the families of leaf-litter spider collected in Northern Vietnam into the following four guilds: 1) orb weavers: Anapidae, Araneidae, Mysmenidae, Tetragnathidae, Theridiosomatidae; 2) sheet-line weavers: Amaurobiidae, Haniidae, Leptonetidae, Linyphiidae, Ochyroceratidae, Pholcidae, Sicariidae, Scytodidae, Telemidae and Theridiidae; 3) cursorial hunters: Clubionidae, Corinnidae, Gnaphosidae, Liocranidae, Lycosidae, Oxyopidae, Pisauridae, Salticidae, Segestriidae and Zodariidae; 4) ambush predators: Atypidae, Ctenidae, Ctenizidae, Dipluridae, Nemesiidae, Oonopidae, Sparassidae and Thomisidae. Among them, web building spiders include web weaver and sheet line weaver guilds, the rest guilds belong to non web building spiders.

\section{RESULTS}

\section{Community structure of leaf-litter spiders in Northern Vietnam}

The species accumulation curves for each region relatively reach an asymptote (fig. 2), the sampling was almost complete at three regions, suggesting that our comparisons of species richness between three regions are valid.

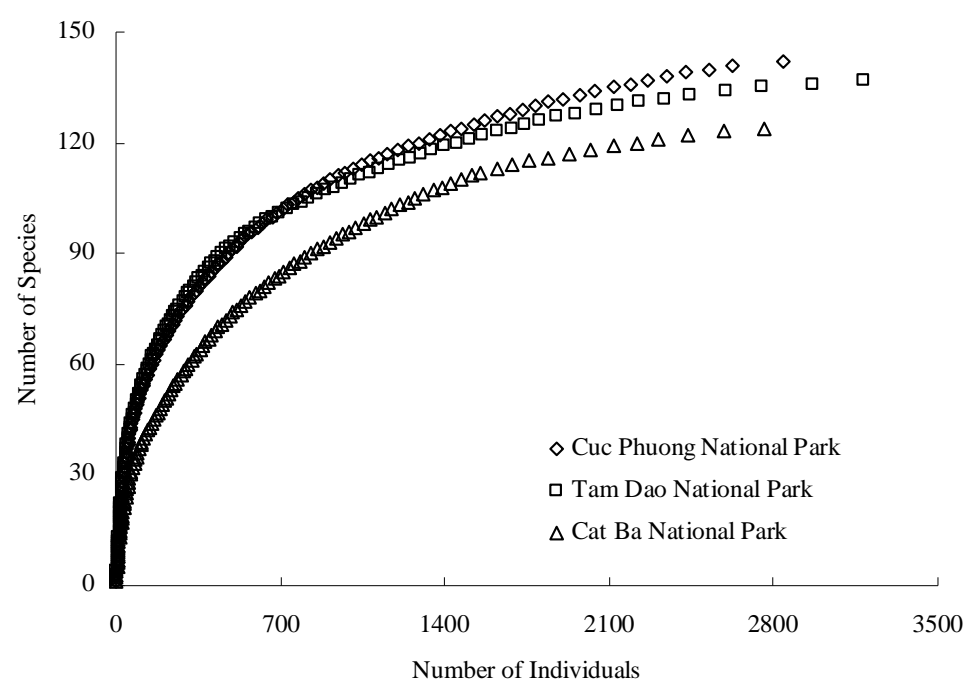

Figure 2. Rarefaction curves of leaf-litter spiders in three regions

Of the total 24,621 specimens collected at three regions Northern Vietnam, there were 8,787 adults. From adult specimens, 251 species of 33 families were identified. The three most abundant families were Linyphiidae $(19.12 \%$ of all captures), Salticidae (13.37\%) and Theridiidae (13.35\%), followed by Lycosidae (9.96\%), Oonopidae (7.89\%), Zodariidae 
(6.05\%), Corinidae (5.44\%), Amaurobidae $(5.35 \%)$, the rest families less than $5 \%$ for one.

The material collected from CPNP consisted of 2,846 adults, 142 species, and 27 families; from TDNP consisted of 3184 adults, 137 species, and 26 families; and from CBNP consisted of 2757 adults, 124 species and 25 families. Twenty families of leaf-litter spiders were collected from all of three regions. The unique families found for CPNP are: Atypidae,
Ochyroceratidae, Segestriidae; for TDNP: Leptonetidae, Sicaridae, Nemesiidae; for CBNP: Dipluridae, Anapidae.

Sheet-line weavers ( $42.43 \%$ of total capture) and cursorial hunters ( $41.16 \%$ of total capture) were the dominant guilds with the highest number of individuals, followed by ambush predators (12.18\% of total capture), lowest was orb weavers (4.23\% of total capture) (fig. 3).

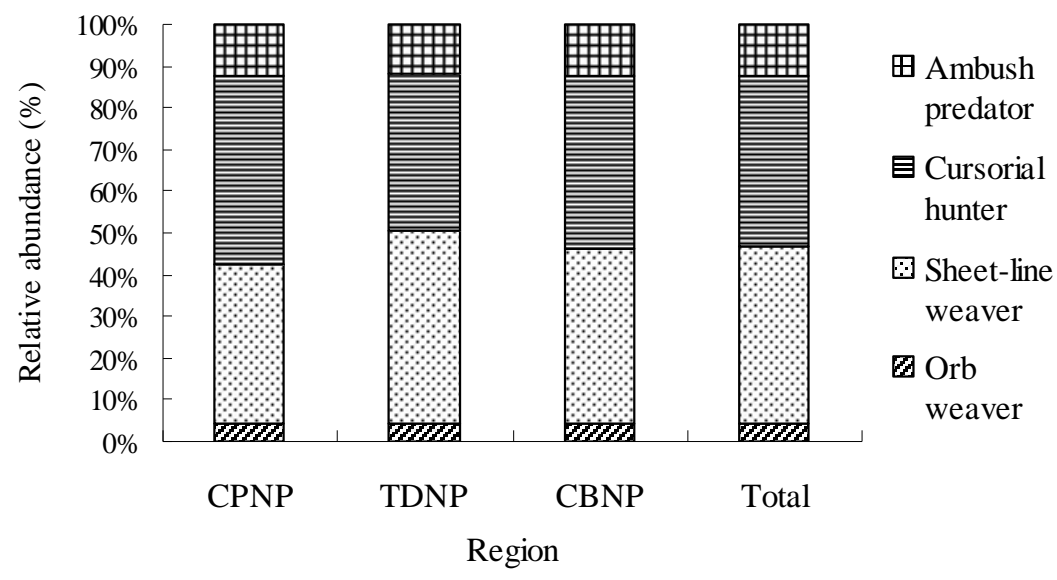

Figure 3. Variation in guild structure of leaf-litter spider assemblages across different

Table 1. Diversity of leaf-litter spider sampled in habitat types of three regions

\begin{tabular}{|c|c|c|c|c|c|c|c|}
\hline Regions & $\begin{array}{c}\text { Habitat } \\
\text { types }\end{array}$ & $\begin{array}{c}\text { Species } \\
\text { number } \\
(S)\end{array}$ & $\begin{array}{c}\text { Individual } \\
\text { number } \\
(N)\end{array}$ & $\begin{array}{c}\text { Species } \\
\text { richness } \\
\text { index } \\
(d)\end{array}$ & $\begin{array}{c}\text { Evenness } \\
\text { index } \\
\left(J^{\prime}\right)\end{array}$ & $\begin{array}{c}\text { Shannon- } \\
\text { Weaver } \\
\text { function } \\
\left(H^{\prime}\right)\end{array}$ & $\begin{array}{c}\text { Simpson } \\
\text { index } \\
(D)\end{array}$ \\
\hline \multirow{6}{*}{ CPNP } & NATF & 95 & 952 & 13.71 & 0.8852 & 4.031 & 0.8749 \\
& DISF & 90 & 742 & 13.47 & 0.8954 & 4.029 & 0.8742 \\
& SHRL & 75 & 607 & 11.55 & 0.8945 & 3.562 & 0.8712 \\
& ACAP & 61 & 545 & 9.52 & 0.8312 & 3.417 & 0.8283 \\
\hline \multirow{5}{*}{ TDNP } & NATF & 90 & 932 & 13.02 & 0.8332 & 3.749 & 0.8588 \\
& DISF & 94 & 1074 & 13.33 & 0.8416 & 3.824 & 0.8641 \\
& SHRL & 68 & 572 & 10.55 & 0.9012 & 3.502 & 0.8685 \\
& ACAP & 61 & 606 & 9.36 & 0.8993 & 3.497 & 0.8664 \\
\hline \multirow{5}{*}{ CBNP } & NATF & 84 & 818 & 12.38 & 0.8987 & 3.982 & 0.8744 \\
& DISF & 94 & 784 & 13.95 & 0.8874 & 4.032 & 0.8725 \\
& SHRL & 74 & 596 & 11.42 & 0.8892 & 3.627 & 0.8688 \\
& ACAP & 66 & 559 & 10.27 & 0.9228 & 3.666 & 0.8736 \\
\hline
\end{tabular}

Number of species, individuals, species richness, evenness, and indices of diversity of leaf-litter spider communities in three typical regions belong to Northern Vietnam are presented in table 1. Evenness and Simpson index were not significantly different among the four types of habitats, while the abundance, species richness index and Shannon-Weaver function were significantly higher in habitats of multi-LVS than habitats of simple-LVS in all 
three regions.

The results of $t$-test also showed the significant difference of Shannon-Weaver function between habitats of multi-LVS and habitats of simple-LVS $(\mathrm{P}<0.01)$ while analysis showed that between habitats of multiLVS and between habitats of simple-LVS were not significantly different $(\mathrm{P}>0.05)$ (table 2$)$.

Table 2. Pair-wise $t$-test the differences of Shannon-Weaver function $\left(H^{\prime}\right)$ between habitats (paired two sample for means, d.F. $=250$ ).

\begin{tabular}{|l|c|c|c|c|c|c|}
\hline \multirow{2}{*}{ Comparison } & \multicolumn{2}{|c|}{ CPNP } & \multicolumn{2}{c|}{ TDNP } & \multicolumn{2}{c|}{ CBNP } \\
\cline { 2 - 7 } & $t$-test & $P(\mathrm{~T} \leq \mathrm{t})$ & $t$-test & $P(\mathrm{~T} \leq \mathrm{t})$ & $t$-test & $P(\mathrm{~T} \leq \mathrm{t})$ \\
\hline NATF vs. DISF & 1.78 & 0.3789 & -0.91 & 0.1809 & 0.35 & 0.3641 \\
NATF vs. SHRL & 2.71 & 0.0036 & 2.46 & 0.0087 & 2.39 & 0.0087 \\
NATF vs. ACAP & 2.39 & 0.0086 & 2.18 & 0.0095 & 2.65 & 0.0043 \\
DISF vs. SHRL & 2.24 & 0.0074 & 3.15 & 0.0009 & 2.47 & 0.0070 \\
DISF vs. ACAP & 2.52 & 0.0069 & 2.89 & 0.0021 & 2.48 & 0.0068 \\
SHRL vs. ACAP & 0.45 & 0.3269 & -0.67 & 0.2518 & 0.71 & 0.2386 \\
\hline
\end{tabular}

Comparison of species and guild composition among three regions

The MDS plots generated from relative abundances of different spider species in sampling sites located in three different regions of Northern Vietnam showed significant difference in clustering pattern (fig. 4). The sites of each region clustered together and distinctly with other regions.

Table 3. Global and pair-wise ANOSIM for differences in species and guild compositions of leaflitter spider assemblages between regions

\begin{tabular}{|l|c|c|c|c|}
\hline \multirow{2}{*}{ Comparison } & \multicolumn{2}{c|}{ (a) Species composition } & \multicolumn{2}{c|}{ (b) Guilds composition } \\
\cline { 2 - 5 } & $\mathrm{R}$ & $\mathrm{p}$ & $\mathrm{R}$ & $\mathrm{p}$ \\
\hline Global & 0.742 & 0.001 & 0.023 & 0.143 \\
CPNP vs. TDNP & 0.615 & 0.001 & 0.047 & 0.094 \\
CPNP vs. CBNP & 0.814 & 0.001 & 0.017 & 0.236 \\
TDNP vs. CBNP & 0.811 & 0.001 & -0.003 & 0.455 \\
\hline
\end{tabular}

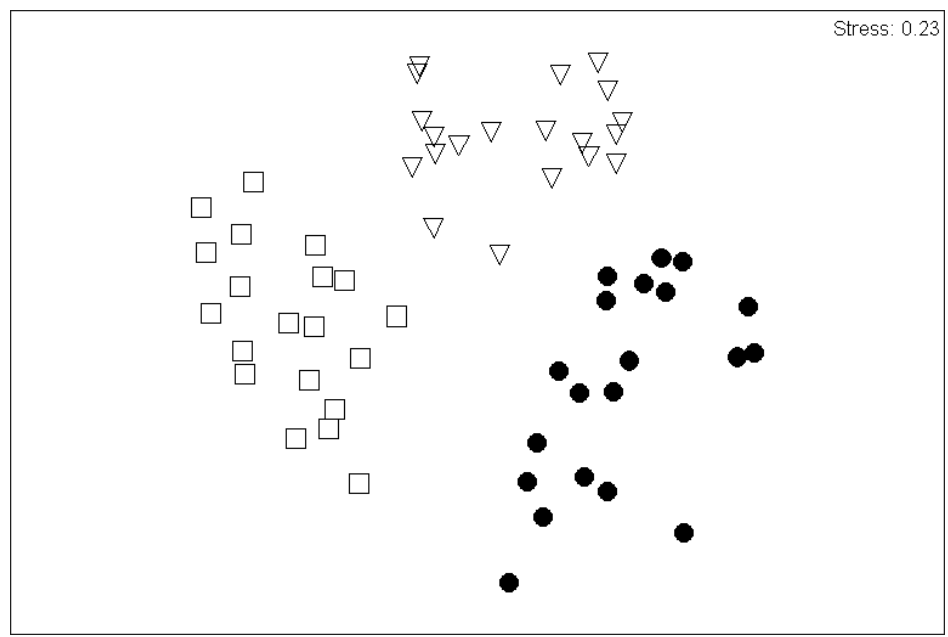

Figure 4. MDS plots of sampling plots in the Northern Vietnam generated by leaf-litter spider species composition sorted according to regions. $(\bullet)$. sites in Cuc Phuong National Park; $(\nabla)$. sites in Tam Dao National Park; (๑). in Cat Ba National Park. 
Results of ANOSIM tests (table 3a) also showed significant difference in species composition of canopy spider abundances between CBNP and CPNP $(R=0.814, P<0.01)$ as well as between CBNP and TDNP $(R=0.811$, $P<0.01)$, while the difference was decreased between CPNP and TDNP $(R=0.615, P<0.01)$. The species composition of leaf-litter spiders of three regions was significantly different and the greatest difference was detected between CBNP and the rest regions.

The MDS plots generated from relative abundances of different spider guilds in three regions showed no obvious clustering pattern (fig. 5).

Results of ANOSIM tests (table 3b) also showed no difference in guild composition between regions $(P>0.5)$.

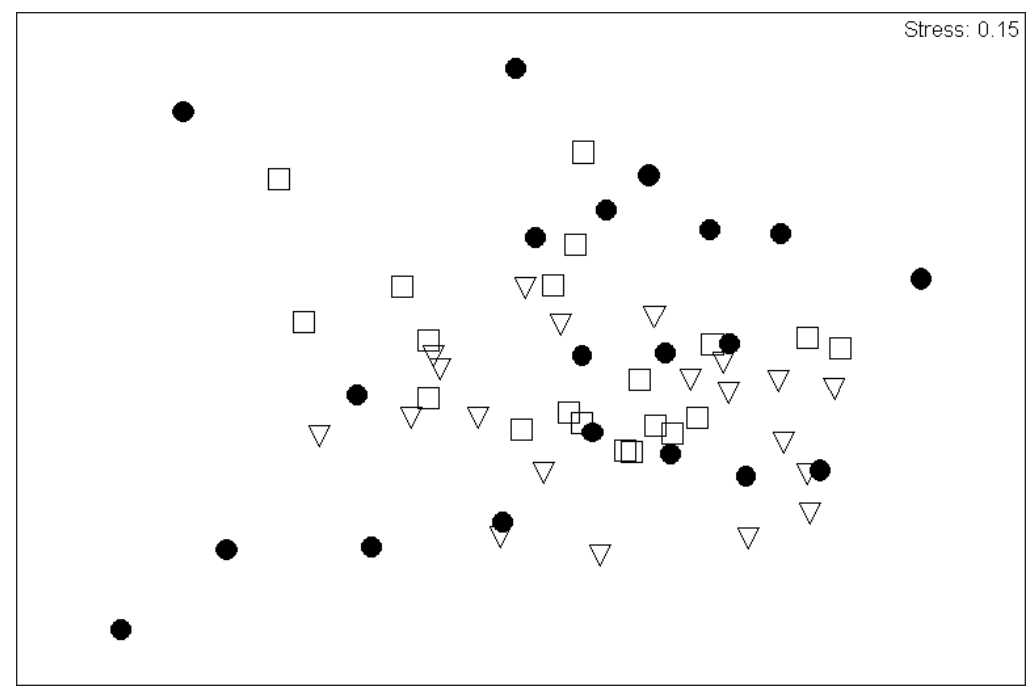

Figure 5. MDS plots of sampling plots in the Northern Vietnam generated by leaf-litter spider guild composition sorted according to regions. $(\bullet)$. sites in Cuc Phuong National Park; $(\nabla)$. sites in Tam Dao National Park; ( $\square)$. in Cat Ba National Park.

Meanwhile the SIMPER analysis indicated that the average dissimilarity (Dis-values) in guild composition between regions was very low (Dis. of CPNP vs. TDNP $=3.60$, CPNP vs. $\mathrm{CBNP}=2.02$, TDNP vs. $\mathrm{CBNP}=3.48$ ).

\section{Comparison of species and guild composition among habitats}

The MDS plots generated from relative abundances of different spider species in habitats showed either the difference in clustering pattern, but also different in significant level in regions as well (fig. 6). The difference in clustering pattern in CPNP and TDNP was more significant than CBNP. The habitats at each region were grouped into two main clusters, the first cluster is comprised type of habitats have simple-LVS, the second cluster included type of habitats have multi-LVS. Results showed that spider species composition was similar between habitats with the same in the vegetation structure and different between two types of vegetation structure.

Pair-wise ANOSIM tests (table 4a) showed the significant difference in species composition of ground-active spider abundances between habitats of multi-LVS and habitats of simpleLVS $(P<0.01)$, except pair-wise between DISF vs. SHRL of CBNP $(P>0.01)$. Results also indicated no significant difference among most of habitats the same in the vegetation structure $(P>0.01)$, except pair-wise between NATF vs. DISF of TDNP $(P<0.01)$.

The MDS plot generated from relative abundances of different spider guilds in habitats showed significant difference in clustering pattern (fig. 7). Sampling sites in habitats have multi-LVS were clustered together and separated from habitats have simple-LVS. 
Pair-wise ANOSIM test also indicated signification differences in guild composition (table $4 \mathrm{~b}$ ). The results showed signification difference in guild composition between
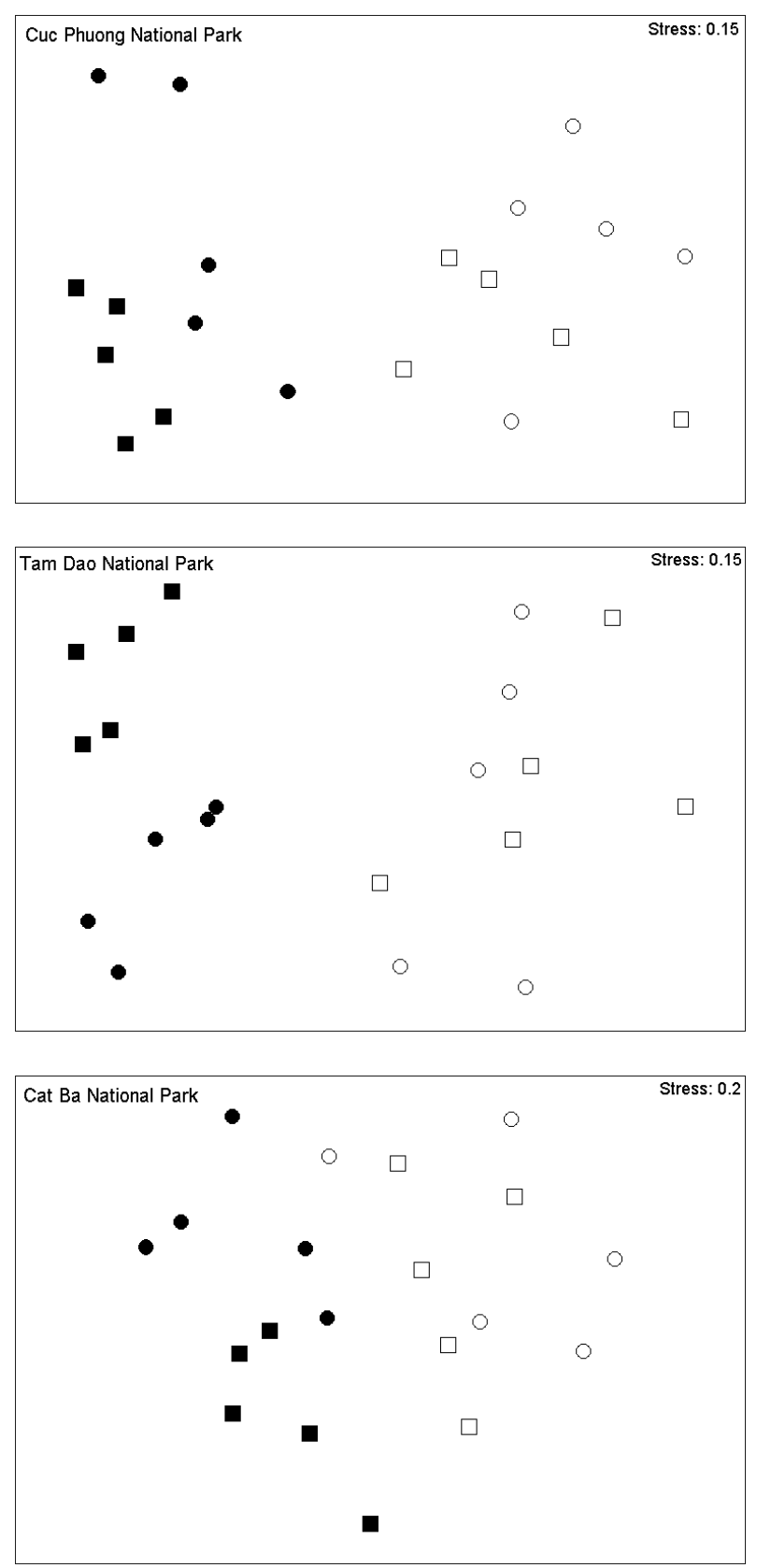

Fig. 6. MDS plots of sampling plots in the Northern Vietnam generated by leaf-litter spider species composition sorted according to habitats. habitats have multi-LVS and habitats have simple-LVS $(P<0.01)$ while similarity in habitats the same in vegetation structure at TDNP $(P>0.01)$.
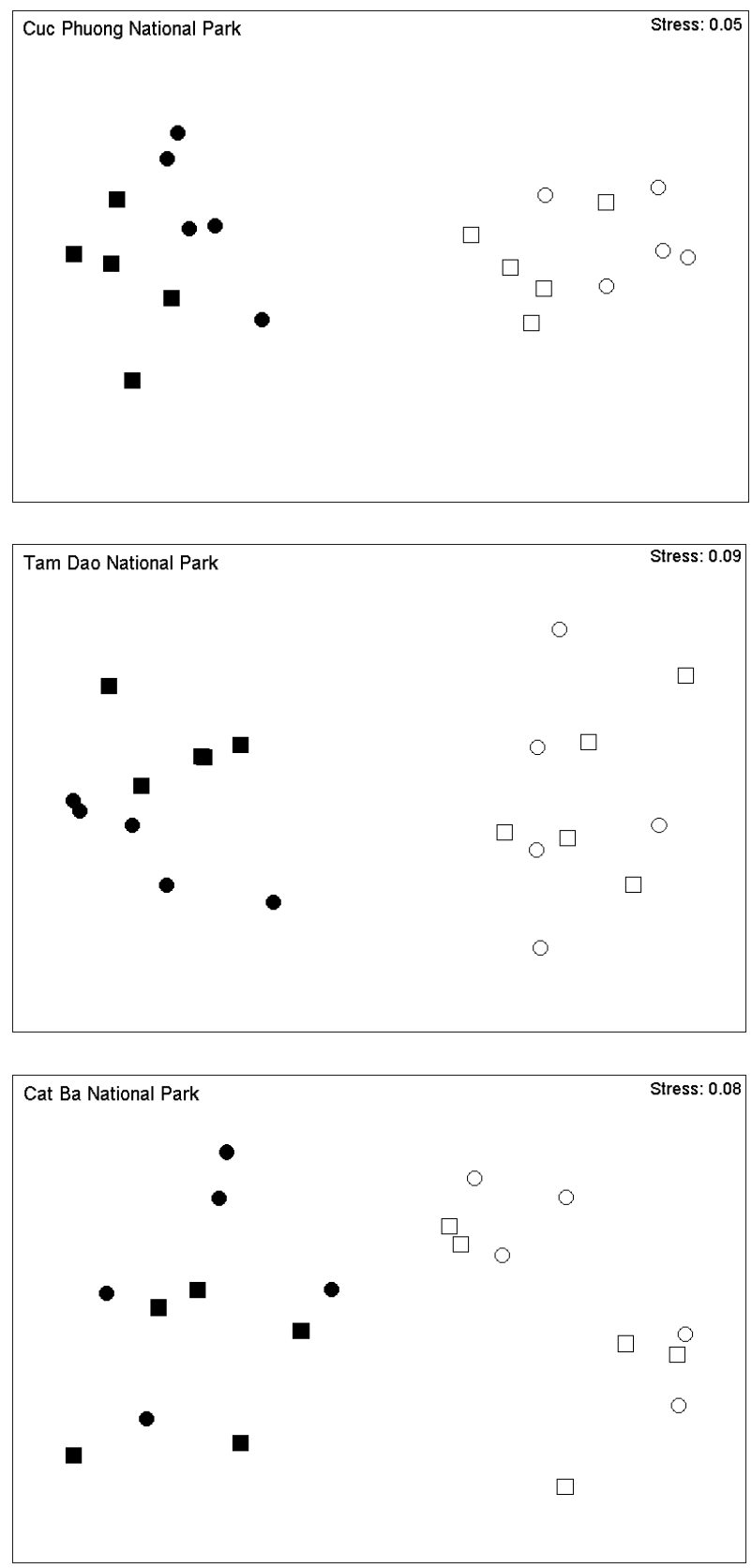

Fig. 7. MDS plots of sampling plots in the Northern Vietnam generated by leaf-litter spider guild composition sorted according to habitats

Close square: natural forest, close circle: disturbed forest, open square: shrub-land, open circle: acacia plantation. 
Table 4. Global and pair-wise ANOSIM for differences in species composition and guild composition of leaf-litter spider assemblages between habitats

\begin{tabular}{|l|c|c|c|c|c|c|}
\hline \multirow{2}{*}{\multicolumn{1}{|c|}{ Comparison }} & \multicolumn{2}{c|}{ CPNP } & \multicolumn{2}{c|}{ TDNP } & \multicolumn{2}{c|}{ CBNP } \\
\cline { 2 - 7 } & $\mathrm{R}$ & $\mathrm{p}$ & $\mathrm{R}$ & $\mathrm{p}$ & $\mathrm{R}$ & $\mathrm{p}$ \\
\hline (a) Species composition & & & & & & \\
Global & 0.694 & 0.001 & 0.804 & 0.001 & 0.521 & 0.001 \\
NATF vs. DISF & 0.344 & 0.016 & 0.660 & 0.008 & 0.304 & 0.016 \\
NATF vs. SHRL & 0.936 & 0.008 & 0.884 & 0.008 & 0.664 & 0.008 \\
NATF vs. ACAP & 0.980 & 0.008 & 0.964 & 0.008 & 0.740 & 0.008 \\
DISF vs. SHRL & 0.736 & 0.008 & 0.808 & 0.008 & 0.292 & 0.048 \\
DISF vs. ACAP & 0.896 & 0.008 & 0.852 & 0.008 & 0.528 & 0.024 \\
SHRL vs. ACAP & 0.192 & 0.151 & 0.012 & 0.437 & -0.224 & 0.090 \\
(b) Guilds composition & & & & & & \\
Global & 0.778 & 0.001 & 0.711 & 0.001 & 0.518 & 0.001 \\
NATF vs. DISF & 0.180 & 0.143 & 0.440 & 0.016 & -0.160 & 0.881 \\
NATF vs. SHRL & 1 & 0.008 & 1 & 0.008 & 0.860 & 0.008 \\
NATF vs. ACAP & 1 & 0.008 & 0.988 & 0.008 & 0.932 & 0.008 \\
DISF vs. SHRL & 0.988 & 0.008 & 0.976 & 0.008 & 0.792 & 0.008 \\
DISF vs. ACAP & 1 & 0.008 & 0.984 & 0.008 & 0.844 & 0.008 \\
SHRL vs. ACAP & 0.484 & 0.024 & -0.048 & 0.579 & -0.164 & 0.952 \\
\hline
\end{tabular}

Results of SIMPER analysis indicated that the most dissimilar pair-wise between habitats at each region were between NATF and ACAP of CPNP, between DISF and SHRL of TDNP and between NATF and ACAP of CBNP. Two guilds sheet-line weavers and cursorial hunters were the contributor to dissimilarity between these pair-wises (table 5).

Table 5. SIMPER analysis of differences in guild composition of leaf-litter spider assemblages between the two most dissimilar habitats of each region

\begin{tabular}{|l|r|l|r|r|r|r|}
\hline Comp & \multicolumn{1}{c|}{ Dis } & \multicolumn{1}{c|}{ Guild } & \multicolumn{1}{c|}{ Ab1 } & \multicolumn{1}{c|}{ Ab2 } & \multicolumn{1}{c|}{ ADis } & \multicolumn{1}{c|}{ Co\% } \\
\hline (a) CPNP & & Orb weaver & 16.20 & 2.40 & 4.66 & 11.76 \\
NATF vs. & \multirow{3}{*}{39.62} & Sheet-line weaver & 78.20 & 33.80 & 14.62 & 36.89 \\
ACAP & & Cursorial hunter & 82.80 & 43.20 & 13.30 & 33.56 \\
& & Ambush predator & 11.40 & 32.40 & 7.05 & 17.79 \\
\hline (b) TDNP & \multirow{3}{*}{3} & Orb weaver & - & - & - & - \\
NATF vs. & \multirow{2}{*}{33.80} & Sheet-line weaver & 110.60 & 51.80 & 18.11 & 53.56 \\
SHRL & & Cursorial hunter & 79.80 & 35.20 & 13.23 & 39.14 \\
& & Ambush predator & - & - & - & - \\
\hline (b) CBNP & \multirow{2}{*}{25.49} & Orb weaver & - & - & - & - \\
NATF vs. & Sheet-line weaver & 74.20 & 46.60 & 10.20 & 40.00 \\
ACAP & & Cursorial hunter & 69.00 & 35.60 & 12.24 & 48.02 \\
& & Ambush predator & - & - & - & - \\
\hline
\end{tabular}

(Comp). comparison; (Dis). average dissimilarity; (Ab). average abundance; (ADis). guild-specific contribution to average dissimilarity; (Co\%). percentage of average dissimilarity due to guild; $(-)$. not significant.

\section{DISCUSSION}

Different habitat structure resulted in different on diversity of leaf-litter spiders had been confirmed by Huhta (1971) [16], Bultman et al. (1982) [7], Bultman and Uetz (1982) [5], Olson (1994) [22], Burgess et al. (1999) [8], 
Vargas (2000) [36], Liski et al. (2003) [19], and Wagner et al. (2003) [40].

The study results of the leaf-litter spiders in Northern Vietnam showed that abundance, species richness and diversity index were higher in habitats have multi-LVS than habitats have simple-LVS. The studies by Huhta (1971), Uetz (1975, 1976 and 1979) [16, 31, 32, 33] indicated diversity of spiders increases with increased litter depth. Maybe increase litter depth in habitats have multi-LVS are cause increase in spider community in those habitats. As litter depth increases, its vertical layers (in differing stages of decomposition) become more distinct. Vertical partitioning of deep litter may be a means by which spider species richness and abundance changes with litter depth [5]. Furthermore, changes in litter depth may affect spider community because of increased litter volume [40]. Increased volume may lead to increased population sizes and therefore lowered extinction rates.

Through not difference in characters of vegetation structure, the species composition of leaf-litter spiders was significantly different between regions. ANOSIM analysis showed that species composition was significantly different between CBNP and the rest regions. CBNP located on an island area that isolated from mainland, the distribution of spider species depends on their aerial dispersal potential and the interaction between patch connectivity and area [3]. Over time and with isolation, the number of species on islands created by fragmentation will, if any, decline. The common characteristis uniting all island systems is isolation, which can result in properties such as a microcosmic nature and a uniquely evolved biota [13]. Possible reasons may be isolation affecting to the share in species composition of spiders between CBNP and others in mainland.

The CPNP belong to the red river delta tropical monsoon climate condition with stability in factors of weather such as temperatures, humidity gradient maybe were support to assemblages of spiders higher at this region. Spider assemblages are highly influenced by ecosystem dynamics such as disturbance, and abiotic factors such as ambient humidity and temperature [4, 3]. Temperature, humidity, and other abiotic factors have been shown to influence the abundance and distribution of spiders [43]. Russell-Smith (2002) [27] showed spider diversity is related to mean annual rainfall. In addition, CBNP affected by maritime climate condition with typhoons and storms that often happened in summer. TDNP belong to typifiles the climate of the high mountains with high wins, heavy rain and fog-bank in most of the time. Maybe these factors also were relative to the assemblages of spiders in study area.

Our study showed that the species composition of leaf-litter spiders was significantly different between habitats of multiLVS and habitats of simple-LVS. Results of SIMPER analysis of differences in guild composition of ground-active spider assemblages between habitats indicated that both guilds are sheet-line weavers and cursorial hunters together in contributors to dissimilarity between habitats of multi-LVS and habitats of simple-LVS. Results also indicated that most of species of sheet-line weavers only found in habitats of multi-LVS, in contrast the species of cursorial hunters were dominant in habitats of simple-LVS.

Abiotic factors, such as moisture, light, and temperature, may influence spider distribution of the litter spiders [11, 25, 40]. Sheet-line weaver spiders such as Amaurobiidae and Linyphiidae may be restricted to the lower litter layers since these smaller spiders have a large ratio of surface area to volume, which could make hygro-thermal regulation more difficult in the upper litter layers [40]. In the habitats of multi-LVS, relative humidity is higher compared to the habitats of simple-LVS. In this take part in support to the assemblages of sheetline weavers at habitats of multi-LVS.

Moreover, the complexity of leaf-litter effect to distribution of spiders [16, 31, 32, 5]. Taxonomic groupings within the diverse spider community of the forest floor exhibit consistent microhabitat segregation correlated with leaflitter complexity [40]. The large sheet-line 
weavers were equally distributed across litter depths [40]. The funnel web design of sheet-line weaver spiders allows them to live in a retreat that is deeper in the litter layer, thereby protecting them from desiccation [26]. The complexity of leaf-litter with the depth higher in habitats have multi-LVS are suitable to the species of sheet-line weavers. In contrast, the larger, cursorial hunter spiders may be able to reside in the habitats of open space since they can more readily relocate to shady or moist locations when temperature and moisture levels are unacceptable [17]. Therefore, habitats having simple-LVS are suitable to the cursorial hunter spiders.

Furthermore, ambient light intensity is another abiotic factor that may influence spider distribution in the leaf litter [40]. With vegetation cover are higher and thus habitats having multi-LVS were darker than habitats having simple-LVS. Decreased light availability in the habitats has multi-LVS in may hinder prey capture by visually oriented cursorial hunter spiders. Although some cursorial spiders possible rely on vibratory cues to locate prey, reliance on visual cues for prey detection is important for Lycosidae and Salticidae [18, 11]. Sheet-line weaver spiders typically have poorly developed eyes [11] and may be less hindered in capturing prey in the darker.

As a result, we suggest that the distribution of leaf-litter spiders affected by habitat structure in relation to abiotic factors such as moisture, light, and temperature that characterized at each type of habitat.

Acknowledgements: The manuscript benefited greatly from comments by Xinping Wang (University of Florida, USA), and Jeremy A. Miller (Netherlands Centre for Biodiversity Naturalis, Leiden, The Netherlands). We are indebted to Tang Guo, Liu Jie, Lin Yuzheng, Zhai Hui, Cao Caixia, Whang Chunxia and Yu Fenglan (Institute of Zoology, Chinese Academy of Sciences), who assisted us with species identification. We thank Luu Van Hien (Cuc Phuong National Park), Vu Van Hieu (Cat Ba National Park), Nguyen Van Ket (Tam Dao National Park) for helping us in field experiments.

\section{REFERENCES}

1. Bell J. R., Wheater C. P., Cullen W. R., 2001. The implications of grassland and heathland management for the conservation of spider communities: a review. Journal of Zoology, 255: 377-387.

2. Bongers F., 2001. Methods to assess tropical rain forest canopy structure: an overview. Plant Ecology, 153: 263-277.

3. Bonte D., L. Baert, L. Lens and Maelfait J. P., 2004. Effects of aerial dispersal, habitat specialisation, and landscape structure on spider distribution across fragmented grey dunes. Ecography: 343-349.

4. Bonte D., L. Baert and Maelfait J. P., 2002. Spider assemblage structure and stability in a heterogeneous coastal dune system. Journal of Arachnology, 30: 331-343.

5. Bultman T. L. and Uetz G.W., 1982. Abundance and Community Structure of Forest Floor Spiders Following Litter Manipulation. Oecologia, 55: 34-41.

6. Bultman T. L. and Uetz G. W., 1984. Effects of structure and nutritional quality on abundance of litter-dwelling arthropods. American Midland Naturalist, 111: 165-172.

7. Bultman T. L., Utez G. W. and Brady A. R., 1982. A comparison of cursorial spider communities along a successional gradient. Journal of Arachanology, 10: 23-33.

8. Burgess N. D., Ponder K. L. and Goddard J., 1999. Surface and leaf-litter arthropods in the coastal forests of Tanzania. African Journal of Ecology, 37: 355-365.

9. Clarke K. R., 1993. Non-parametric multivariate analyses of changes in community structure. Australian Journal of Ecology, 18:117-143.

10. Do Duc Tien, 2001. Tam Dao National Park. Agricultural Publishing House, Hanoi: 102pp.

11. Foelix R., 1996. Biology of Spiders, 2nd Ed. Oxford University Press. New York: 330 pp. 
12. Frith D. and Frith C., 1990. Seasonality of litter invertebrate populations in an Australian upland tropical rain forest. Biotropica, 22: 181-190.

13. Gillespie R. G. and G. K. Roderick, 2002. Arthropods on islands: colonization, speciation, and conservation. Annual Review of Entomology, 47: 595-632.

14. Hofer H. and Brescovit A. D., 2001. Spiders and guild structure of a neotropical spider assemblage (Araneae) from Reserva Duck, Amazonas. Brazil. Andrias, 15: 99-119.

15. Horn H. S., 1971. The adaptive geometry of trees. Monographs in population biology 3 . Princeton. University Press, Princeton. 146 pp.

16. Huhta V., 1971. Succession in the spider communities of the forest floor after clearcutting and prescribed burning. Annales Zoologici Fennici, 8: 483-542.

17. Humphreys $\quad$ W. G., 1987. Behavioural temperature regulation. In, Ecophysiology of spiders (ed. W. Nentwig) SpringerVerlag, Berlin, Germany.

18. Land M. F., 1985. The morphology and optics of spider eyes. In, Neurobiology of Arachnids. (ed Barth, F.G.) SpringerVerlag, Berlin, 53-78.

19. Liski J. A., Nissinen A., Erhard M. and Taskinen O., 2003. Climate effects on litter decomposition from artic tundra to tropical rainforest. Global Change Biology, 9: 575584.

20. Maelfait J. P., F. Hendrickx, 1998. Spider as bio-indicators of anthropogenic stress in natural and semi-natural habitats in Flanders (Belgium): some recent developments. In PA Selden, ed. Proceedings of the 17th European Colloquium of Arachnology, Edinburgh 1997. Burnham Beeches, Bucks, British Arachnological Society: 293-300.

21. Moretti M., Conedera M., Duelli P., Edwards P. J., 2002. The effects of wildfire on ground-active spiders in deciduous forests on the Swiss southern slope of the Alps. Journal of Applied Ecology, 39: 321-336.

22. Olson D. M., 1991. A comparison of the efficacy of litter sifting and pitfall traps for sampling leaf litter ants (Hymenoptera, Formicidae) in a tropical wet forest, Costa Rica. Biotropica, 23: 166-172.

23. Olson D. M., 1994. The distribution of leaflitter invertebrate along a neotropical altitudinal gradient. Journal of Tropical Ecology, 10: 129-150.

24. Primer-E Ltd., 2001. Primer 5 for Windows. Version 5.2.4. Ivybridge: Primer-E Ltd.

25. Pultz R., 1987. Thermal and water relations. In, Ecophysiology of Spiders (ed. W. Nentwig) Springer-Verlag, Berlin, Germany.

26. Riechert S. E., 1976. Web-site selection in the desert spider Agelenopsis aperta. Oikos, 27: 311-315.

27. Russell-Smith A., 2002. Comparison diversity composition ground-active spiders Mkomazi Game Reserve, Tanzania Etosha National Park, Namibia. Journal of Arachnology, 30(2): 383-388.

28. Sørensen L. L., 2004. Composition and diversity of the spider fauna in the canopy of a montane forest in Tanzania. Biodiversity and Conservation, 13: 437-452.

29. Stevenson B. G. and Dindal D. L., 1982. Effect of leaf shape on forest floor spiders: Community organization and microhabitat selection of immature Enoplognatha ovata (Clerck) (Theridiidae). Journal of Arachnology, 10: 165-178.

30. Thai Van Trung, 2000. Forest vegetation of Vietnam. Science and Technology Publishing House, Hanoi, Vietnam.

31. Uetz G. W., 1975. Temporal and spatial variation in species diversity of wandering spiders (Araneae) in deciduous forest litter. Environmental Entomology, 4: 719-724.

32. Uetz G. W., 1976. Gradient analysis of spider communities in a stream-side forest. Oecologia (Berl), 22: 373-385.

33. Uetz G. W., 1979. The influence of variation in litter habitats on spider communities. Oecologia, 40: 29-42.

34. Uetz G. W., 1991. Habitat structure and 
spider foraging. In: Bell S. S., McCoy E. D. \& Mushinsky H.R. (eds), Habitat Structure: 325-348. The Physical Arrangement of Objects in Space. Chapman \& Hall, London.

35. Uetz G. W., 1999. Guild structure of spiders in major crops. Journal of Arachnology, 27: 270-280.

36. Vargas A. J., 2000. Effects of fertilizer addition and debris removal on leaf-litter spider communities at two elevations. The Journal of Arachnology, 28: 79-89.

37. Vo Quy, Nguyen Ba Thu, Ha Dinh Duc and Le Van Tac, 1996. Cuc Phuong National Park, Agricutural Publishing House, Hanoi, Vietnam.

38. Wagner J. D. \& Wise D. H., 1996. Cannibalism regulates densities of young wolf spiders: evidence from field and laboratory experiments. Ecology, 77(2): 639-652.
39. Wagner J. D. \& Wise D. H., 1997. Influence of prey availability and conspecifics on patch quality for a cannibalistic forager: laboratory experiments with the wolf spider Schizocosa. Oecologia, 109: 474-482.

40. Wagner J. D., Toft S. and Wise D. H., 2003. Spatial stratification in litter depth by forestfloor spiders. The Journal of Arachnology, 31: 28-39.

41. Weeks R. D. and T. O. Holtzer, 2000. Habitat and seasons in structuring grounddwelling spider (Araneae) communities in a shortgrass steppep ecosystem. Environmental Entomology, 26: 1164-1172.

42. Willett T. R., 2001. Spiders and other arthropods as indicators in old-growth versus logged redwood stands. Restoration Ecology, 9: 410-420.

43. Wise D. H., 1993. Spiders in Ecological Webs. University Press, Cambridge, UK.

\title{
ĐA DẠNG NHỆN Ở THẢM LÁ RỤNG RÙ̀NG NHIÊTT ĐỚI MIỀN BẮC VIỆT NAM TRONG MỐI LIỂN QUAN TỚI ĐIỂU KIỆN VÙNG VÀ CẤU TRÚC MÔI TRƯờNG SỐNG
}

\author{
Phạm Đình Sắc ${ }^{1}$, Trần Thị Anh Thư ${ }^{2}$, Li Shuqiang ${ }^{3}$ \\ ${ }^{(1)}$ Viện Sinh thái và Tài nguyên sinh vật \\ ${ }^{(2)}$ Trường Đại học Cần Thơ \\ ${ }^{(3)}$ Viện Động vật học, Viện Hàn lâm Khoa học Trung Quốc
}

\section{TÓM TÁ́T}

Nhện sống trong tầng lá rụng đã được tiến hành khảo sát tại ba vườn quốc gia phía Bắc Việt Nam với điều kiện thời tiết khác nhau bao gồm: vườn quốc gia Cúc Phương (khí hậu nhiệt đới gió mùa đồng bằng sông hồng), vườn quốc gia Tam Đảo (khí hậu nhiệt đới gió mùa vùng núi cao) và vườn quốc gia Cát Bà (khí hậu biển). Bốn sinh cảnh được chọn để khảo sát tại mỗi vùng bao gồm: rừng tự nhiên và rừng bị tác động (có cấu trúc thảm thực vật kiểu đa tầng), bụi rậm và rừng keo (có cấu trúc thảm thực vật kiểu đơn tầng). Nhện được thu bằng phương pháp rây lá rụng. Tổng số 8.787 cá thể nhện trưởng thành thuộc 251 loài và 33 họ thu được từ ba khu vực nghiên cứu, bao gồm 2.846 cá thể thuộc142 loài ở vườn quốc gia Cúc Phương, 3184 cá thể thuộc 137 loài ở vườn quốc gia Tam Đảo và 2.757 cá thể thuộc 124 loài ở vườn quốc gia Cát Bà. Phương pháp thống kê MDS và ANOSIM được sử dụng để so sánh sự đa dạng của nhện giữa các vùng và các sinh cảnh. Thành phần loài nhện khác nhau rõ rệt giữa vùng có khí hậu biển so với các vùng khác. Các chỉ số đa dạng sinh học cao hơn ở các sinh cảnh có cấu trúc thảm thực vật đa tầng. Thành phần loài nhện khác nhau rõ rệt giữa hai loại sinh cảnh có cấu trúc thảm thực vật khác nhau. Mối liên quan giữa đa dạng của nhện và đặc điểm cấu trúc của các loại sinh cảnh đã được thảo luận trong bài báo.

Từ khóa: cấu trúc thảm thực vật, đa dạng, điều kiện vùng, nhện trong thảm lá rụng, rừng nhiệt đới, miền Bắc Việt Nam.

Ngày nhận bài: 2-2-2012 